\title{
WILL COLLARED LEMMINGS AND THEIR PREDATORS BE THE FIRST VERTEBRATES TO “FALL OVER THE CLIFF” IN GREENLAND DUE TO GLOBAL CLIMATE CHANGES?
}

\author{
Olivier Gilg ${ }^{1,2}$, Benoît Sittler ${ }^{2,3}$, And IlkKa Hanski ${ }^{4}$ \\ ${ }^{1}$ Université de Bourgogne, Lab Biogéosciences, UMR CNRS 5561, \\ Dijon, France. E-mail: olivier.gilg@gmail.com \\ ${ }^{2}$ Groupe de Recherche en Ecologie Arctique, 16 rue de Vernot, Francheville, France \\ ${ }^{3}$ Institut für Landespflege, Université of Freiburg, Tennenbacherstrasse 4, 79106 \\ Freiburg, Germany \\ ${ }^{4}$ Department of Biology and Environmental Science, P.O. Box 65, \\ o0014 University of Helsinki, Finland
}

\begin{abstract}
Extended Abstract.-The high-Arctic has the world's simplest terrestrial vertebrate predator-prey community, with the Collared Lemming (Dicrostonyx groenlandicus) being the single main prey of four predators, the Snowy Owl (Bubo scandiacus), Arctic Fox (Vulpes lagopus), Long-tailed Skua (Stercorarius longicaudus), and Stoat (Mustela erminea). Using a 20-year time series (Figure 1) and a model that has been previously parameterized with data from northeast Greenland (Gilg et al. 2003), we analysed the population and community level consequences of the ongoing and predicted climate change. Species' responses are complex, because in addition to the direct effects of climate change, which vary depending on species' life histories, species are affected indirectly through interactions with their prey and predator species. The lemmingpredator community exemplifies these complications, yet a robust conclusion emerges: in practically all scenarios and for the ranges of parameter values examined, climate change increases the length of the lemming population
\end{abstract}

cycle and decreases the maximum densities reached during the fluctuations (Gilg et al. 2009). The latter change, in particular, is detrimental to populations of their predators, which are adapted to make use of the years of prey abundance (Gilg et al. 2006). Indeed, in northeast Greenland, even the Gyrfalcon is strongly dependent on lemmings, for the densities of larger prey, such as Arctic Hare (Lepus arcticus) and ptarmigan are too low in most years.

Therefore, climate change will indirectly induce a decline in predators' reproductive success and population densities, and may ultimately lead to local extinctions of some of the predator species (Gilg et al. 2009, Post et al. 2009). Based on these results, we conclude that the recent anomalous observations of lemming population dynamics (Figure 1) may well be the first signs of a severe impact of climate change on the lemming-predator communities in northeast Greenland and presumably also elsewhere in the high-Arctic. Received 7 April 2011, accepted 15 April 2011. 
Gilg, O., B. SitTler, AND I. Hanski. 2011. Will Collared Lemmings and their predators be the first vertebrates to "fall over the cliff" in Greenland due to global climate changes? Extended abstract, pages 131-132 in R. T. Watson, G. Hunt, T. J. Cade, M. Fuller, and E. Potapov (Eds.). Gyrfalcons and Ptarmigan in a Changing World, Volume I. The Peregrine Fund, Boise, Idaho, USA. http://dx.doi.org/ 10.4080/gpcw.2011.0113

Key words: Arctic, Greenland, lemming, population cycle, disruption, climate change.

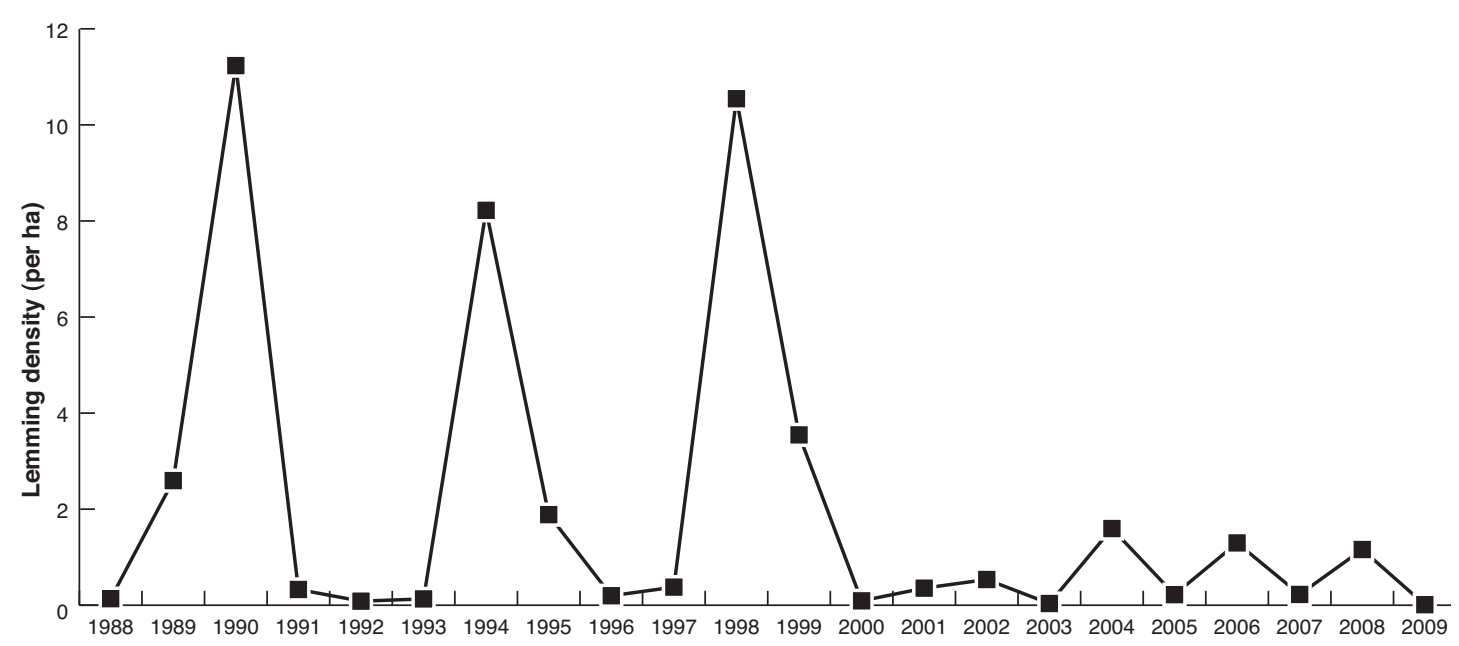

Figure 1. Lemming density in northeast Greenland from 1988 through 2009, showing the recent (since 2000) disruption of the 4-year cycle in peak density observed from 1988 through 2000.

\section{Literature Cited}

Gilg, O., I. Hanski, AND B. Sittler. 2003. Cyclic dynamics in a simple vertebrate predator-prey community. Science 302:866-868.

Gilg, O., B. Sittler, AND I. Hanski. 2009. Climate change and cyclic predator-prey population dynamics in the high-Arctic. Global Change Biology 15:2634-2652.

Gilg, O., B. SitTler, B. Sabard, A. Hurstel, R. Sané, P. Delattre, and I. Hanski. 2006. Functional and numerical responses of four lemming predators in high arctic Greenland. Oikos 113:196-213.
Post, E., M. C. Forchhammer, M. S. BretHarte, T. V. Callaghan, T. R. ChrisTENSEn, B. Eberling, A. D. Fox, O. Gilg, D. S. HIK, T. T. HøYE, R. A. IMS, E. JePPESen, D. R. Klein, J. Madsen, A. D. MCGuire, S. RYSGAARD, D. E. SCHINDLER, I. Stirling, M. P. TAmstorf, N. J. C. TYler, R. VAN DER WAL, J. WELKER, P. A. WOOKEY, N. M. SCHMIDT, AND P. AASTRUP. 2009. Ecological dynamics across the Arctic associated with recent climate change. Science 325:1355-1358. 